\title{
A Study on Linkage between Corporate Social Entrepreneurship and Brand Building
}

\author{
Dr. Pragya Jaroliya ${ }^{1}$, Dr. Deepak Jaroliya ${ }^{2}$, Yamini Modi ${ }^{3}$ \\ ${ }^{1}$ Associate Professor, School of Management, SVVV, Indore \\ ${ }^{2}$ Associate Professor, Prestige Institute of Management \& Research, Indore \\ ${ }^{3}$ Asst. manager (ER), Human Resource Department, IOCl, Gujarat Refinery, Vadodara \\ ${ }^{1}$ pragyajaroliya@yahoo.co.in, ${ }^{2}$ deepak_jaroliya@yahoo.com, ${ }^{3}$ yaminimodi6@gmail.com
}

\begin{abstract}
Nowadays Corporates are more focused on practicing social entrepreneurship and hence have diverted their business goals towards exercising Corporate Social Entrepreneurship (CSE), derived from the wider concept of Corporate Social Responsibility (CSR), as a strategy to address social problems majorly like Poverty, Unemployment, etc. in a way that maximizes performance and improves the overall stakeholder wellbeing. To achieve their high-minded goals, the corporates might partner with government or philanthropic entities, fund specific programs and work on either the local or global level. Such practices build a competitive advantage with a social impact on society. It's a mechanism to genuinely address social problems while remaining associated with a higher purpose. Though the companies are venturing ways to address a social problem, it is necessary to ascertain the perceived value of the same amongst the Organization and its impact on business goals to achieve higher brand equity. Hence, the study focuses on deriving the linkage between Corporate Social Entrepreneurship and Corporate Brand Building through a structured modeling technique as a methodology via primary data collection
\end{abstract}

Keywords

social entrepreneurship, Corporate Social Entrepreneurship, Corporate Social Responsibility, social impact, brand building

Article Received: 10 August 2020, Revised: 25 October 2020, Accepted: 18 November 2020

\section{Introduction}

Corporate Social Entrepreneurship (CSE) is a new concept of doing business however, in a short period, the concept of CSE has already been discussed expansively in the media as well over many social platforms. The entrepreneurs involved in the concept of social entrepreneurship develop their social preferences along with the well-defined principles of businesses. This results in the formation of a new business model. Presently, it is noticeable that the concept of social entrepreneurship is emerging rapidly in terms of size, scope and support. An exceptional number of organizations are using social entrepreneurship as a stratagem to deal with social problems like poverty, hunger, at-risk youth, recidivism etc. These steps taken by an organization to understand and address the social problems may increase the overall value of the organization, as a large number of audiences are interested to understand these initiatives. This also enhances the scope of doing business with such organizations as the social enterprises have a big story to share by shaping perceptions; this may contribute to the organization's branding. Indirectly, it also brings attention to internal and external communications, customer and employee engagement and it helps to build an organization that everyone wants to work with. A promising number of start-ups are beginning with the objective of serving and to bring out positive social and environmental changes. These individuals are considered as social entrepreneurs and their organizations treated as socially responsible organizations.

As many organizations face challenges due to competitive markets and putting a lot of effort to develop competitive differentiation. This has brought a phenomenon change in the organizational work culture and many organizations started adopting the model of Corporate Social Entrepreneurship (CSE) by paying attention to CSR practices voluntarily in order to strengthen and to uphold the brand value that indirectly enhances their work efficiency also. Non-Profit Organizations, with a focus on donors and beneficiaries, have also adopted marketing tools that are meant for the commercial sector (Kaur, R., Kumar, B., 2020). Thus, CSE could be considered a stronghold of an organization with one ear on social benefits and the other on organizational needs its practices that additionally provides assurance to its stakeholders also. An increase in corporate governance has a significant effect on firm's financial performance (Shukla, 2020). Hence, the link between entrepreneurship and CSR has become essential, also the concept of CSR is required to be categorized and be better controlled in view not to get trapped into cost factor and to more enlighten the concept of CSR. It can be argued that as an organization initiates the concept of CSE in the core business strategies and is taken on a serious note, not as a fashion, then most likely it contributes towards the value enhancement of the organization's brand. An attempt is made by the researcher through this study to understand Corporate Social Entrepreneurship and its impact on corporate branding.

This study aims to empirically analyze the opinion of various organizations for Corporate Social Responsibility, by applying a panel data regression model. The researcher expects to find a relation between brand equity and CSE because CSE has now become an integral part of companies' brand value. Thereby, it will support a significant and positive relation between CSE and company performance. However, as markets unfold rapidly, it has been observed that the stakeholder's demand, trends and preferences pertaining to products and/or services are continuously 
changing. Thus, with the growing concept of CSR, CSE has become a valuation set-up for corporates by being able to respond to their customers' and stakeholders' needs, which has broadened over the period. As specified in the literature, CSR found to have grown from a narrow and marginalized concept into a complex and flexible concept (Cochran, 2007). Although there is no substantially accepted definition and framework of CSR, it 'won the battle of ideas' as said by Crook (2005) and corporates have included CSR practices in their business goals and strategies with the new growing concept of Corporate Social Entrepreneurship (CSE), thereby realizing the importance of it. Accordingly, this study has tried to understand the concept of CSE by going through CSR (for social impact), Corporate Entrepreneurship and Social Entrepreneurship (for strategies) has become essential. Therefore, these three concepts are directed to entrepreneurs that make the business strategies to promote the growth, earn profit (respectively CE) and thereby address customers and/or stakeholder's requirements, needs and promote the company's brand and add value to it (respectively CSE).

Using social entrepreneurship exclusively as a marketing aid runs the risk of missing $n$ number of opportunities from the point of view of business purpose as well as benefiting society at large. Deriving the most positive of these opportunities requires hard work, focus, long-term commitments and most importantly, a shift in the thought process. One of the recent strategic orientation is "Brand Orientation" that has been discussed and pondered upon in for-profit-sector. Previously, a lot of research work has been carried out on CSE, where researchers have paid attention to principle and on the processes underlying unprecedented entrepreneurial activity (Luke, B., Chu, V., 2013). However, still there is a need to carried out the research focusing on how does the CSE contributes to the brand-building process as well as enhances brand awareness, reputation, equity etc. In this paper the linkage between Corporate Social Entrepreneurship and Corporate Brand Building being analyzed by using primary data.

\section{Review Of Literature}

In the review of literature, the researcher aims to analyze the relationship between Corporate Social Entrepreneurship and the concept of branding, being explained thoroughly in the following sections:

\section{Corporate social responsibility}

Barnes J (2011) studied CSR and its effect on brand trust by administering respondents with the dimensions of Turker's CSR scale (2009) and the Delgado-Ballester brand trust scale (2004) revealed that a variance of $22 \%$ on brand trust has been explained by CSR. The brand trust variance is lower with regard to a less socially responsible company as compared to the variance of a socially responsible company. The higher the company is socially responsible, the larger the effect of CSR on brand trust.

Austin and Refico (2009) concluded that CSE is the more advanced and powerful form of CSR. Hence, if companies tend to shift their CSR activities from the conventional end and move their societal and environmental commitment to the next higher level, then they will have to amend their current perspective towards CSR strategies and practices, utilizing the creativity of each and every individual. CSE, resembling all entrepreneurship activities, is more about creating sustainable change in pursuit of new opportunities rather than managing existing operations or CSR programs. With the entrepreneurial redesign, systems development, and necessary action, it brings the eagerness and desire to create homogenized social and economic value.

\section{Social entrepreneurship}

According to the McKinsey survey (2010), it was being observed that 76 percent of organizational executives believed that CSR enhances the financial position of the organization and the shareholder value in the long run. It was also suggested by researchers that with the instrumentality of CSE and related activities, the loyalty of customers towards a brand increases and brand image improves. Such benefits had been taken into account in many studies as important elements towards the enlargement of CSE concepts amongst the business community (Maignan et al., 1999).

In the field of social affairs, many researchers established the significance of social entrepreneurs to work out with social problems and thus endorse social entrepreneurship. Social entrepreneurship can be defined as the approach of utilizing the resources to craft societal benefits. The person who strives through innovative ideas and risk-taking behavior to benefit society is called a social entrepreneur(Tracey et al. 2007). Hartigan (2006) believes that social entrepreneurship follows a progressive way of entrepreneurship transformation. social entrepreneurship warrants building, pursuing and evaluating opportunities for transformative change in society, effected by passionate and dedicated individuals. This definition involves entirely fresh, innovative and ingenious models based on identified opportunities.

In the special report of The Global Entrepreneurship Monitor (GEM), 2016, social entrepreneurship has been defined as "any activity, organization or initiative that has a particular social, environmental or community objective". However, research is in a ongoing debate on whether social enterprises are not-for-profit or for-profit enterprises. Over the last few years, the concept of 'social entrepreneurship' has been rigorously emerging in the public, non-profit and private sectors (Anderson et al., 2006). Social entrepreneurship is paramount in developing countries, where differences in terms of economic discrimination and social development still exist (Chell 2007).

In recent years, Social Entrepreneurship has become an inseparable part of India. India is underway of developing an environment that supports social entrepreneurs with mentoring, as incubators and provides financial support (Ghani et al., 2013). Social enterprises are progressing towards earning brand value by being a source of innovative ideas towards providing products \& services to the underprivileged section of society. 


\section{Corporate social entrepreneurship}

According to Abu-Saifan (Abu-Saifan 2012), CSEs can be categorized into mission-driven and profit-driven organizations. Mission-driven CSEs achieve self-sustenance by performing a blend of social and commercial entrepreneurial activities. By contrast, CSEs with a profitdriven strategy align social purpose with the core business and simultaneously performs commercial and social entrepreneurial activities to achieve viability in the market. Agrawal and Sahasranamam (2016) analyzed how the corporate sector in India can create economic and social value through corporate social entrepreneurial activities. It also examines three corporate social enterprises namely ITC (E-choupal), ICICI (ICICI Foundation), Doshion water management service ltd. (Project Swasth) and illustrates how societal needs have been addressed by utilizing corporate history, organizational resources, and institutional environment, through subsequent use of commercial means. Hemingway (2005) shows that the manager's values are motivators for corporate social entrepreneurship. The study also addresses how values act as drivers of our actions and pay attention to the values of the entrepreneur, thereby linking corporate social responsibility with the existing debate on moral agency. Austin \& Reavis (2002) explored that Corporates like Motorola, Cisco and Philips have successfully integrated CE into their business strategies and models, while Starbucks and Timberland are already considered as pioneers of CSE practices.

Branding

One of the research has specifically defined brand Orientation as an approach in which the process of the organization remains concerned with the creation, development and protection of brand identity in continuous interaction with identified customers to achieve persistent competitive advantages in the form of brands [Urde, 1999. p. 117-118]. From a cultural perspective, brand orientation can also be defined as a positive node of corporate culture or as a particular way of organization's thinking. Urde suggested that the means of involving the brands and its competency are the fundamentals for the development of the brand [p. 123]. An earlier study has proposed insights into the alignment of vision, culture and image (Hatch \& Schultz 2001 ; 2008) and works closely with the ideas of the brandoriented corporation. The behavioral perspective of brand orientation includes the significance accorded to the internal quayside (mission, vision, and values) of the brand identity (Baumgarth 2010; de Chernatony 2010; Ind 2007; Ind \& Bjerke 2007; Punjaisri \& Wilson 2007; de Chernatony et al. 2003; Mitchell 2002). Also, Psychological factors do have an impact on influencing the brand preferences of consumers (Madan, 2020). One of the qualitative studies which was based on interaction with well-established social entrepreneurs showed that brand orientation is one of the most relevant strategic orientations to at least a few of the successful CSEs (Schmidt \& Luckenbach, 2013).

\section{Objectives Of The Study}

To study the linkage between Corporate Social Entrepreneurship and Corporate Brand Building, the following research questions being proposed:

- Research Question 1: Does Brand Awareness positively and directly affects Brand Equity.

- Research Question 2: Does Corporate Social Entrepreneurship positively and directly affects Brand Equity.

- Research Question 3: Does Corporate Image positively and directly affects Brand Equity.

\section{Methodology}

\section{Research Design and Sampling Technique}

The researcher has used exploratory cum descriptive research design for the study as the researchers want to study the relationship between the dependent variable and the independent variable. Further, Non-Probabilistic Convenience Sampling has been used to carry out the present study as it is not possible to estimate the exact number of employees working in the organization and are aware of Corporate Social Entrepreneurship.

\section{Sample for the study}

The present study is based on primary data. The relevant data has been collected from a sample of 400 respondents. These respondents have been taken as the employees working in the organizations involved in Corporate Social Entrepreneurship.

\section{The instrument for Data Collection}

For instrument development, variables being identified using a review of the literature and theoretical foundation based on research objectives were considered. Depending on the Data Sensitivity required the variable was converted into questions with appropriate levels were developed and then converted into the final instrument. A structured questionnaire with the help of experts in the area of Corporate Social Entrepreneurship was developed.

\section{Pretesting procedures}

Pre-testing of the questionnaire was carried out qualitatively as well as quantitatively to eliminate any ambiguity, and ensure its readability, validity, reliability and flow. For qualitative testing of the questionnaire, opinions were sought of five eminent personalities. Feedbacks were collected about the questionnaire and necessary changes were incorporated into it. For quantitative testing, the Cronbach Alpha Reliability Test was carried out. It is a measure of internal consistency which states how closely a set of items are related to that of a group. A "high" value of alpha acts as evidence (along with substantive arguments and other statistical measures) that the items measure the latent construct. 


\section{Reliability Test of an Instrument}

Cronbach Alpha value of the instrument is 0.826 which is nearer to 0.70 hence the reliability of the construct Corporate Social Entrepreneurship is good. Moreover, in the item-wise list, not a single statement is having Cronbach Alpha greater than 0.826 . Hence, we cannot delete any of the statements. So the construct is reliable.

\section{Result And Analysis}

\section{Demographic Profile of Respondents}

The present study being conducted with a sample size of 400 respondents, brief of their demographic profile is as under:

Out of 400 respondents, 44.8 percent are males and 55.3 percent are females forming a ratio of 9:11 respectively. Considering the major parameter of Age and education, around 25.8 percent falls in the age group of 21 to 30 years; 26 percent in 31 to 40 years, 27.8 percent in 41 to 50 years and rest i.e. 20.5 percent represent above 51 years of age group. Followed by education, 15.3 percent are undergraduates, 34.3 percent graduate, 36.5 percent postgraduates and 14 percent have completed professional courses.

Organizations have their demographic parameters in terms of the number of employees, Years of experience and hierarchy of management etc. As per the study, out of 400 respondents, 35 percent are working in the organization having 10 to 50 employees, 34.8 percent are working in the organization having 50 to 100 employees, 13.3 percent are working in the organization having 100 to 500 employees, 17 percent are working in the organization having more than 500 employees. Further, 24.3 percent falls in the category of experience of less than 1 year, 24 percent are having experience of 1 to 2 years, 27.3 percent are having experience of 2 to 3 years, 13 percent are having experience of 3 to 4 years and 11.5 percent are having experience of more than 5 years. Talking about the hierarchy, which ranges from Lower management, Middle Management, Upper Middle Management to the highest of Organization i.e. top management. The study reveals their profile as 28.5 percent, 29.5 percent, 25.3 percent and 16.8 percent respectively. Proceeding towards the focus of study which is majorly on Corporate Social Entrepreneurship, hence studying its demographic template becomes essential. One of the templates speaks about the awareness of the CSE concept of business amongst the employees which as per the study appears to be 52.3 percent of the respondents being aware, 47.8 percent are unaware of the same. Continuing with other templates, 35 percent of respondents have allotted funds less than 0.49 percent, 34.8 percent in the range of 0.5 to 1.00 percent, 13.3 percent in the range of 1.00 to 1.99 percent, 17 percent in the range of funds above 2.00 percent to Corporate Social Entrepreneurship as a percentage of Business Profit. Out of which, 51.3 percent of the population has not contributed and 48.8 percent have contributed in any capacity in Corporate Social Entrepreneurship of the company.

\section{Structural equation modeling}

To uncover the relationship between corporate social entrepreneurship and brand building a Structure Equation Modeling (SEM) analysis was conducted on the collected data. AMOS 18 software-based hypothesized Technology Acceptance Model was tested.

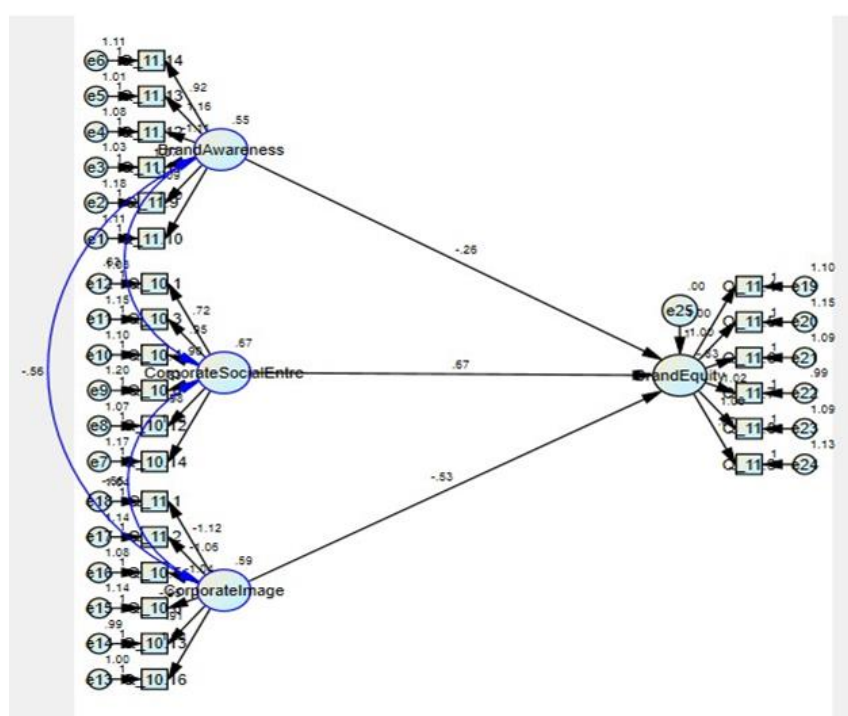

Figure 1: Structural Equation Modeling

To meet the research objective in line with research questions, three hypotheses being proposed as follow:

Linkage/Research Problem 1:

H1. Brand Awareness positively and directly affects Brand Equity.

Linkage/Research Problem 2:

H2. Corporate Social Entrepreneurship positively and directly affects Brand Equity.

Linkage/Research Problem 3:

H3. Corporate Image positively and directly affects Brand Equity.

Table 1.1: Showing Relation Between Constructs

\begin{tabular}{|l|r|r|r}
\hline Relation Between Constructs & Estimate & P-Value & Null Hypothesis \\
\hline Brand Awareness $\rightarrow$ Brand Equity & 0.263 & 0.855 & Fail to Reject \\
\hline $\begin{array}{l}\text { Corporate Social Entrepreneurship } \rightarrow \text { Brand } \\
\text { Equity }\end{array}$ & 0.667 & 0.002 & Reject \\
\hline Corporate Image $\rightarrow$ Brand Equity & 0.530 & 0.000 & Reject \\
\hline
\end{tabular}

Examination of the path coefficients and the significance level between the constructs in the model was used to test the hypotheses. The analysis in the above table shows that Corporate Social Entrepreneurship has a positive significant relationship with Brand Equity.

Hypothesis

H0: Relationships do not exist between these constructs.

H1: Relationships exist between these constructs.

Table 5.2(a): Model Fit Summary (CMIN)

\begin{tabular}{|l|r|r|r|r|r|}
\hline Model & NPAR & CMIN & DF & P & CMIN/DF \\
\hline Default model & 54 & 408.934 & 246 & .000 & 1.662 \\
\hline Saturated model & 300 & .000 & 0 & & \\
\hline Independence model & 24 & 3495.962 & 276 & .000 & 12.667 \\
\hline
\end{tabular}


Table 5.2(b): Model Fit Summary (RMR, GFI)

\begin{tabular}{|l|r|r|r|r}
\hline Model & RMR & GFI & AGFI & PGFI \\
\hline Default model & .062 & .924 & .907 & .758 \\
\hline Saturated model & .000 & 1.000 & & \\
\hline Independence model & .564 & .261 & .197 & .240 \\
\hline
\end{tabular}

Table 5.2(c): Model Fit Summary (Baseline Comparisons)

\begin{tabular}{|l|r|r|r|r|r|}
\hline Model & $\begin{array}{r}\text { NFI } \\
\text { Delta1 }\end{array}$ & $\begin{array}{r}\text { RFI } \\
\text { rho1 }\end{array}$ & $\begin{array}{r}\text { IFI } \\
\text { Delta2 }\end{array}$ & $\begin{array}{r}\text { TLI } \\
\text { rho2 }\end{array}$ & CFI \\
\hline Default model & .883 & .869 & .950 & .943 & .949 \\
\hline Saturated model & 1.000 & & 1.000 & & 1.000 \\
\hline Independence model & .000 & .000 & .000 & .000 & .000
\end{tabular}

Table 5.2(d): Model Fit Summary (Parsimony-Adjusted Measures)

\begin{tabular}{|l|r|r|r|}
\hline Model & PRATIO & PNFI & PCFI \\
\hline Default model & .891 & .787 & .846 \\
\hline Saturated model & .000 & .000 & .000 \\
\hline Independence model & 1.000 & .000 & .000 \\
\hline
\end{tabular}

Table 5.2(e): Model Fit Summary (NCP)

\begin{tabular}{l|r|r|r}
\hline Model & NCP & LO 90 & HI 90 \\
\hline Default model & 162.934 & 111.215 & 222.546 \\
\hline Saturated model & .000 & .000 & .000 \\
\hline Independence model & 3219.962 & 3032.927 & 3414.328 \\
\hline
\end{tabular}

Table 5.2(f): Model Fit Summary (FMIN)

\begin{tabular}{|l|r|r|r|r|}
\hline Model & FMIN & F0 & LO 90 & HI 90 \\
\hline Default model & 1.025 & .408 & .279 & .558 \\
\hline Saturated model & .000 & .000 & .000 & .000 \\
\hline Independence model & 8.762 & 8.070 & 7.601 & 8.557 \\
\hline
\end{tabular}

Table 5.2(g): Model Fit Summary (RMSEA)

\begin{tabular}{|l|r|r|r|r|}
\hline Model & RMSEA & LO 90 & HI 90 & PCLOSE \\
\hline Default model & .041 & .034 & .048 & .988 \\
\hline Independence model & .171 & .166 & .176 & .000 \\
\hline
\end{tabular}

Table 5.2(h): Model Fit Summary (AIC)

\begin{tabular}{|l|r|r|r|r|}
\hline Model & AIC & BCC & BIC & CAIC \\
\hline Default model & 516.934 & 524.153 & 732.473 & 786.473 \\
\hline Saturated model & 600.000 & 640.107 & 1797.439 & 2097.439 \\
\hline $\begin{array}{l}\text { Independence } \\
\text { model }\end{array}$ & 3543.962 & 3547.171 & 3639.757 & 3663.757 \\
\hline
\end{tabular}

Table 5.2(i): Model Fit Summary (ECVI)

\begin{tabular}{|l|r|r|r|r|}
\hline Model & ECVI & LO 90 & HI 90 & MECVI \\
\hline Default model & 1.296 & 1.166 & 1.445 & 1.314 \\
\hline Saturated model & 1.504 & 1.504 & 1.504 & 1.604 \\
\hline $\begin{array}{l}\text { Independence } \\
\text { model }\end{array}$ & 8.882 & 8.413 & 9.369 & 8.890 \\
\hline
\end{tabular}

Table 5.2(j): Model Fit Summary (HOELTER)

\begin{tabular}{|l|r|r|}
\hline Model & HOELTER & HOELTER \\
& .05 & .01 \\
\hline Default model & 277 & 294 \\
\hline Independence model & 37 & 39 \\
\hline
\end{tabular}

The significance of the relationship between the constructs is established as the null hypothesis is rejected on the ground that the pvalue of Chi-Square is less than 0.05. The minimum discrepancy is indicated by CMIN/DF $=1.662$. The recommended value is less than 5 . This means that model fits the data well. The standardized RMR, across all standardized residuals, represents the average value and ranges from 0.00 to 1.00 . This value will be small (say, .05 or less) in a well-fitting model. The value of Root Mean Square Residual $(\mathrm{RMR})=0.062$ shown in the above table represents the unstandardized residual value. In this model Goodness of Fit Index (GFI) $=0.924$ and Adjusted Goodness of Fit Index (AGFI) $=0.907$ which is considered to be a good fit. Although both indices range between 0.00 to 1.00 , with values nearer to 1.00 being indicative of a good fit. In this model, Normed Fit Index (NFI) $=0.883$, Comparative Fit Index $(\mathrm{CFI})=0.949$, Relative Fit Index $(\mathrm{RFI})=0.869$, Incremental Fit Index $(\mathrm{IFI})=0.950$ and Tucker Lewis Index $(\mathrm{TLI})=0.943$ which again shows that model fits well. The ideal value of all these indices should be greater than 0.9. The root means a square error of approximation (RMSEA) is also called the Badness of Fit Index. This model is having Root Mean Square Error Approximation (RMSEA) $=0.041$ which suggests a good fit. The confidence interval (90 percent) of RMSEA is between a LO of 0.071 and a HI of 0.114. Thus, the upper bound is close to .08. It shows that data fit the proposed model very well. 
5.2(k): Regression Weights: (Group number 1 - Default model)

\begin{tabular}{|c|c|c|c|c|c|c|c|}
\hline & & & Estimate & S.E. & C.R. & $\mathrm{P}$ & Label \\
\hline BrandEquity & $<---$ & brand awareness & -.263 & 1.437 & -.183 & .855 & \\
\hline BrandEquity & $<--$ & Corporatelmage & -.530 & 1.251 & -.424 & .672 & \\
\hline BrandEquity & $<---$ & CorporateSocialEntre & .667 & .299 & 2.228 & .026 & \\
\hline Q_11.10 & $<---$ & brand awareness & 1.000 & & & & \\
\hline Q_11.9 & $<--$ & brand awareness & 1.093 & .111 & 9.807 & $* * *$ & \\
\hline Q_11.11 & $<---$ & brand awareness & 1.071 & .107 & 10.034 & $* * *$ & \\
\hline Q_11.12 & $<---$ & brand awareness & -1.113 & .110 & -10.094 & $* * *$ & \\
\hline Q_11.13 & $<---$ & brand awareness & 1.160 & .111 & 10.411 & $* * *$ & \\
\hline Q_11.14 & $<---$ & brand awareness & .923 & .101 & 9.141 & $* * *$ & \\
\hline Q_10.14 & $<---$ & CorporateSocialEntre & 1.000 & & & & \\
\hline Q_10.12 & $<---$ & CorporateSocialEntre & .983 & .092 & 10.704 & $* * *$ & \\
\hline Q_10.8 & $<---$ & CorporateSocialEntre & .830 & .088 & 9.455 & $* * *$ & \\
\hline Q_10.4 & $<---$ & CorporateSocialEntre & .897 & .088 & 10.138 & $* * *$ & \\
\hline Q_10.3 & $<---$ & CorporateSocialEntre & .951 & .092 & 10.339 & $* * *$ & \\
\hline Q_10.1 & $<---$ & CorporateSocialEntre & .718 & .079 & 9.056 & $* * *$ & \\
\hline Q_10.16 & $<---$ & Corporatelmage & 1.000 & & & & \\
\hline Q_10.13 & $<--$ & Corporatelmage & .908 & .091 & 10.003 & $* * *$ & \\
\hline Q_10.6 & $<---$ & Corporatelmage & -.950 & .096 & -9.881 & $* * *$ & \\
\hline Q_10.5 & $<---$ & Corporatelmage & -1.036 & .099 & -10.490 & $* * *$ & \\
\hline Q_11.2 & $<---$ & Corporatelmage & -1.062 & .101 & -10.478 & $* * *$ & \\
\hline Q_11.1 & $<---$ & Corporatelmage & -1.118 & .102 & -10.958 & $* * *$ & \\
\hline Q_11.4 & $<---$ & BrandEquity & 1.000 & & & & \\
\hline Q_11.5 & $<--$ & BrandEquity & 1.004 & .102 & 9.878 & $* * *$ & \\
\hline Q_11.6 & $<---$ & BrandEquity & -.828 & .092 & -9.029 & $* * *$ & \\
\hline Q_11.7 & $<---$ & BrandEquity & 1.019 & .099 & 10.324 & $* * *$ & \\
\hline Q_11.8 & $<---$ & BrandEquity & 1.005 & .100 & 10.022 & $* * *$ & \\
\hline Q_11.3 & $<--$ & BrandEquity & .869 & .095 & 9.174 & $* * *$ & \\
\hline
\end{tabular}

To uncover the relationship between corporate social entrepreneurship and brand building an SEM analysis was conducted on the collected data. This analysis shows that the brand image increases or decreases with one unit change in corporate social entrepreneurship changes, given that other variables are constant. Furthermore, the fact that the relationship is not caused by a coincidence as the causal relationship was proven to be statistically significant. Corporate Social Entrepreneurship significantly affects Brand Image. The regression equation according to the structural equation modeling is given below:

Brand Image $=0.667 *$ Corporate Social Entrepreneurship.

This means that an increase in one unit of Corporate Social Entrepreneurship increases the Brand Equity by 0.667 units.

\section{Conclusion And Suggestions}

Today, as customers and/or stakeholders are becoming more apprehensive towards sustainability-related issues, the importance of CSE is increasing as well. CSE has become one of the objectives of the organization and has brought the attention of stakeholders too. Though the implementation of CSE produces a synergy of social and economic value, in this era of a dynamic and competitive market, it is crucial to establish the brand and make it a part of the life of society. To achieve the same, it is essential to make society aware of the existence of a brand which in turn calls for creating Brand Awareness.
In the present scenario, most of the companies are engaged in different CSE activities to meet the demand of their customers which provides an opportunity for a company to create Brand Awareness via CSE as a strategic marketing tool to enhance brand equity i.e. the perceived value of a brand. Hence, building brand equity in the first instance requires familiarity of the brand amongst the people i.e. creating Brand Awareness. This study rationally affirms this construct that Brand Awareness has a positive impact on the Brand Equity of an Organization.

Once the CSE has done its part as a tool for creating brand awareness, it draws corporate's attention towards building Brand Equity. In our present study, we have instated this fact too that the Brand Equity of any corporate goes hand in hand with corporate social entrepreneurship activities. In this direction of building brand equity, corporates will first have to develop Corporate Social Entrepreneurship activities that have social effects to benefit the society, improve the economic condition and living standards of their employees and workers and protect the environment. Also, they should conduct training programs to help employees work towards achieving this goal of the organization. It is important to understand that Brand Equity can only be stabilized once the support from all stakeholders is in the court of the Organization. The involvement of stakeholders such as public and private organizations, government programs is a must so that organizations can gain the honor and certification of being the most philanthropic enterprise and expedite the implementation and endorsement of CSE activities to achieve the desired Brand Equity. 
Association of any organization with government, Public and Private entities to carry out CSE activities, will provide benefit to the organization in terms of the higher likelihood that the brand image of products and/or services will have a higher acknowledgment from their consumers, clients and business associates that too with a higher level of firm reputation and trust of all stakeholders. This study accordingly has proven the fact that CSE activities have a proportionate effect on the brand image of an organization i.e an organization can enhance its brand image by advancing its corporate social entrepreneurship and therefore enough efforts should be initiated in this direction. To summarize, it can be concluded that the scale of the brand image of Services and commodities produced/provided by the organization and the scale of firm reputation will depend on the CSE activities adopted \& implemented; as well as on the mode of communication of such CSE actions because they have a significant positive effect on the brand image.

In turn, it can be seen that corporates are adopting Corporate Social Entrepreneurship as an integral part of their Organization not only to supplement the Brand Awareness but also to build their reputation i.e. brand image and thereby give a sound impact on the brand equity. To make CSE a culture amongst the employees also, it is required to develop a working environment where employees and workers share their experiences and work as a team so that everyone collectively works towards achieving the organizational goal. It is to be ensured that the products and/or services have a higher level of preference among the consumers as compared to other similar products and/or services offered in the market, by the companies which are not directly or indirectly involved in CSE activities. This will indeed boost the level of reputation and will significantly increase the brand image of such products and/or services.

\section{References}

[1] Abu-Saifan, S. (2012). Social Entrepreneurship. Technology Innovation Management Review, 2, 22-27.

[2] Agrawal, A. and Sahasranamam, S. (2016). Corporate social entrepreneurship in India. South Asian Journal of Global Business Research, 5(2), 214-233. Retrieved from https://doi.org/10.1108/SAJGBR-12-20140098.

[3] Anderson, R. B., Dana, L. P., \& Dana, T. E. (2006). Indigenous land rights, entrepreneurship, and economic development in Canada: "opting-in" to the global economy. Journal of World Business, 41(1), 45-55.
[4] Austin, J., \& Reavis, C. (2002). Starbucks and conservation international (Harvard Business School Case Study No. 303055). Cambridge, MA: Harvard Business School.

[5] Austin, J. E., and Reficco. E. (2009). Corporate Social Entrepreneurship. Harvard Business School Working Paper, No. 09-101.

[6] Baumgarth, C. (2010). Living the brand: brand orientation in the business-tobusiness sector. European Journal of Marketing, 44, 653-671.

[7] Chell, E. (2007). Social Enterprise and entrepreneurship: Towards a convergent theory of the entrepreneurial process. International Small Business Journal, 25(1), 5-26. Retrieved from http://doi.org/10.1177/0266242607071779

[8] Cochran, P. L. (2007). The evolution of corporate social responsibility. Business Horizons, 50(6), 449-454. http://dx.doi.org/10.1016/j.bushor.2007.06 .004

[9] Crook, C. (2005), "The Good Company". The Economist: Special Report.

[10] De Chernatony, L., Drury, S., Segal-Horn, S. (2003). Building a Services Brand. The Service Industries Journal, 23, 1-21.

[11] De Chernatony, L. (2010). From brand vision to brand evaluation, 3rd ed., Amsterdam, Butterworth-Heinemann, 327.

[12] Ghani, E., Kerr, W. R., \& O'Connell, S. (2013). Spatial determinants of entrepreneurship in India. Regional Studies, 48, pp. 1071-1089 http://doi.org/10.1080/00343404.2013.839 869.

[13] Hartigan, Pamela. (2006). It's about people, not profits. Business Strategy Review, 17, 42 - 45. Retrieved from https://doi.org/10.1111/j.09556419.2006.00433.x.

[14] Hatch, M. J., Schultz, M. (2001). Are the strategic stars aligned for your corporate 
brand?. Harvard Business Review, 79, 128-134.

[15] Hatch, M. J., Schultz, M. (2008). Taking brand initiative: How Companies Can Align Strategy, Culture, and Identity Through Corporate Branding, San Francisco, Jossey-Bass, 11-12.

[16] Hemingway, Christine. (2005). Personal Values as A Catalyst for corporate Social Entrepreneurship. Journal of Business Ethics - J BUS ETHICS, 60, 233-249. Retrieved from https://doi.org/10.1007/s10551-005-01325.

[17] Ind, N. (2007). Living the brand: How to Transform Every Member of Your Organization Into a Brand Champion, 3rd ed., London, Kogan Page, 79-80.

[18] Ind, N., Bjerke, R. (2007). The concept of participatory market orientation. Journal of Brand Management, 15, 135-145.

[19] Kaur, R., Kumar, B. (2017). Market Orientation in non-profit organizations. NMIMS Management Review, 35(3), 5571.

[20] Luke, B., Chu, V. (2013). Social enterprise versus social entrepreneurship. International Small Business Journal, 31, 764-784.

[21] Light, B. P. C. (2006). Reshaping social entrepreneurship. Stanford Social Innovation Review, Fall 2006.

[22] Maignan, I., O. C. Ferrell, and T. Hult (1999). Corporate Citizenship: Cultural Antecedents and Business Benefits, Journal of the Academy of Marketing Science, 27(4), 455-469.

[23] Mair, J. (2008). Social entrepreneurship: taking stock and looking ahead. World Entrepreneurship Forum, IESE Business School, 1-17.

[24] Madan, A. (2020). Connecting with Indian Rural Consumers-A Structural Equation Model of Consumer Brand Preference. NMIMS Management Review. 38 (2), 123-145.
[25] McKinsey. (March 31, 2010). How companies manage sustainability: Mckinsey global survey results. Retrieved from https://www.mckinseyquarterly.com.

[26] Mitchell, C. (2002). Selling the brand inside. Harvard Business Review, 80, 90105.

[27] Punjaisri, K., Wilson, A. (2007). The role of internal branding in the delivery of employee brand promise. Journal of Brand Management, 15, 57-70.

[28] Shukla, M. (2020). Efficacy of Corporate Governance in Determining Firm Performance: A Panel Data Approach. NMIMS Management Review. 38 (3), 3954.

[29] Schmidt, H. J ., Lückenbach, F. (2013). Brand Orientation of "Social Businesses". Scientific publications of the department Economics, Koblenz University of Applied Sciences, 13.

[30] Tracey, P., Phillips, N., \& Haugh, H. (2007). Beyond Philanthropy: Community Enterprise as a Basis for Corporate Citizenship. Journal of Business Ethics, 58(4), 327-344. Retrieved from http://dx.doi.org/10.1007/s10551-0046944-x.

[31] Urde, M. (1999). Brand Orientation. Journal of Marketing Management, 15, 117-133. 